\title{
Emperor Tiberius and His praecipua legionum cura in a New Bronze Tablet from AD 14
}

\author{
Peter ROTHENHÖFER*
}

In memoriam

$M^{a}$ José Rubio Fuentes, collaborator of the Centro CIL II at the Universidad Alcalá de Henares

\section{Introduction}

In the Roman Empire, important state documents and administrative decisions were often presented to the public on durable material. For instance, huge bronze tablets were inscribed with the texts of such documents and then fixed on walls in public places, like the copies of the senatus consultum de Cn. Pisone patre or the lex Irnitana. ${ }^{1}$ Many of them have provided important insights into the ancient world. However, the vast majority of finds of inscribed bronze documents consists of small and minute fragments that were already crushed in antiquity for remelting. ${ }^{2}$ In most cases they are only of limited value for historians since a proper reconstruction is impossible. From time to time, however, we come across fragments that allow new historical conclusions, like in the following case.

\section{The monument}

Three adjoining fragments of a huge inscribed bronze tablet (fig. 1), ${ }^{3}$ all with the same green patina. Intentionally broken, like in many other cases for remelting. Total height around $19 \mathrm{~cm}$, width around $16 \mathrm{~cm}$, thickness ca. $0.5-0.6 \mathrm{~cm}$. At the end of line 1 we find a suspension hole for a nail in the upper right corner of the tablet.

The heading gives the consular date, but only the last four letters of the name of one of the consuls are preserved. Before the abbreviation COS a small triangular point can be observed. There are also horizontal lines visible between which the letters are incised.

There is space between the bigger heading line and the main text. We have to take into consideration that maybe a precise date or other information might have been engraved on the lost parts of this line. An incised horizontal line above the first line of the main text offers support for this hypothesis.

The surviving part of the main text consists of 13 smaller lines. The letter heights in these lines are between $0.7-1 \mathrm{~cm}$. The text is well preserved and easy to read.

${ }^{*}$ Prof. Dr. Peter Rothenhöfer, Department of History, Sun Yat-Sen University, Zhuhai Campus, Haibin Hong Lou No. 10, Tangjia, Xiangzhou District, Zhuhai 519082, P. R. China (p.rothenhoefer@yahoo.com; https://orcid.org/0000-0002-5882-1843).

I am grateful to Sven Günther (Changchun), Yuanwei Zhang (Zhuhai) and Filippo Battistoni (Pisa) for useful comments.

${ }^{1}$ Text and commentary of the senatus consultum are published by Eck - Caballos - Fernández 1996; for the lex Irnitana see González 1986 and Wolf 2011.

${ }^{2}$ See e.g. Caballos Rufino et al. 2018 on small inscribed bronze fragments from the Baetican municipium of Baelo Claudia.

${ }^{3}$ The fragments are part of a private collection and were consigned to Jesús Vico y Asociados S.L., Subasta $156\left(5^{\text {th }}\right.$ March 2020), Lot 2060. 


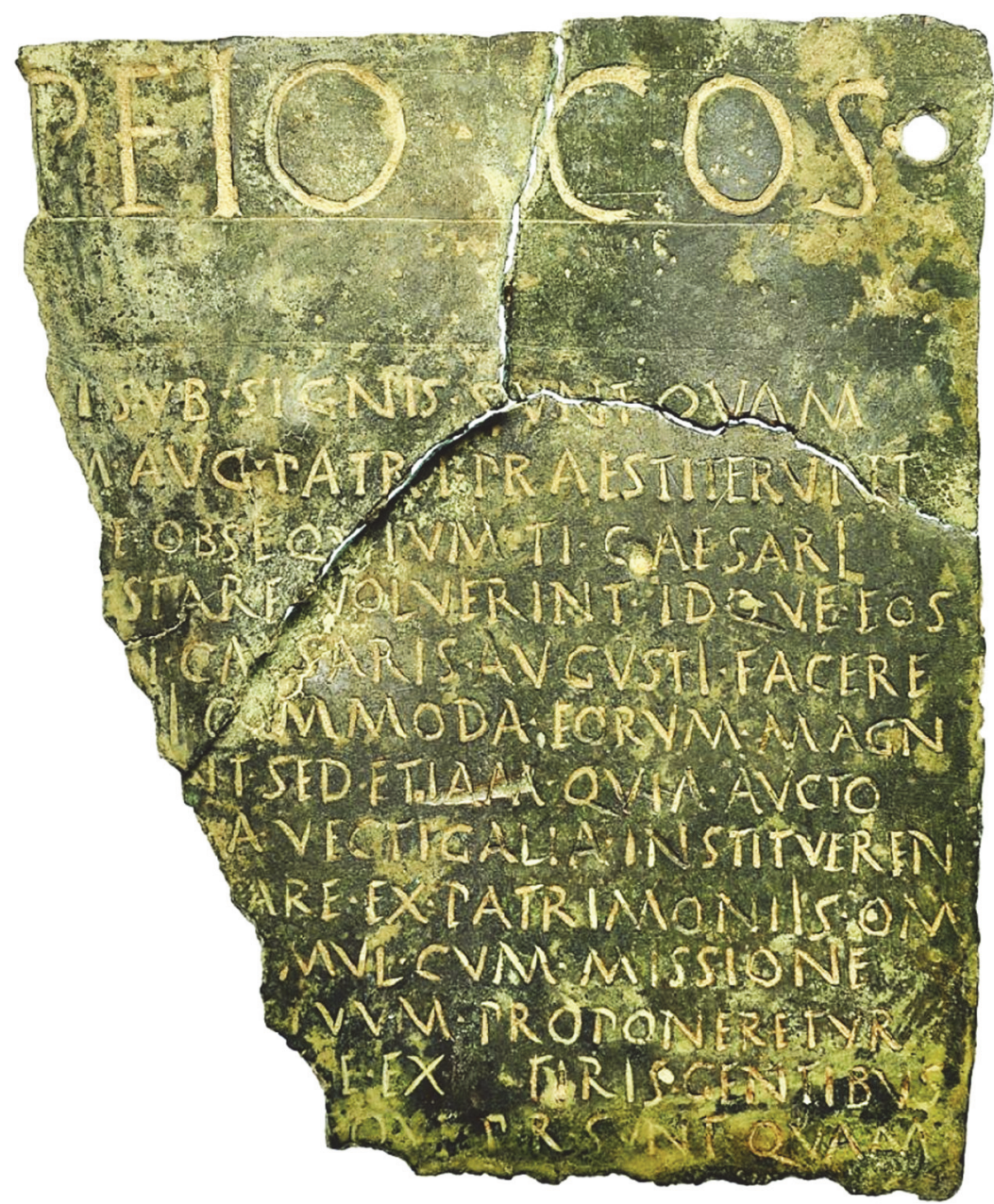

\section{Text reconstruction and translation}

Text:

[- - - $\mathrm{PEIO} \bullet \mathrm{COS}$

[- - - ]VI • SVB • SIGNIS • SVNT QVAM

[- - ]M •AVG • PATRI • PRAESTITERVNT

(4)

[- - ]E • OBSEQVIVM TI • CAESARI

[- - ]ESTARE VOLVERINT • IDQVE • EOS

(6)

[- - ]TI • CAESARIS • AVGVSTI • FACERE

(7)

[- - ]I • COMMODA • EORVM • MAGN

(8)

[- - ]NT • SED • ETIAM • QVIA • AVCTO

(9)

[- - ]VA • VECTIGALIA • INSTITVEREN

[- - ]TARE $\bullet$ EX $\bullet$ PATRIMONIIS $\bullet$ OM

[- - ]IMVL $\bullet$ CVM $\bullet$ MISSIONE

[- - ]ITVVM • PROPONERETVR

[- - -]SE・EX . TIRIS • GENTIBVS

[- - ]TO $\bullet \mathrm{VT} \bullet \mathrm{P} \bullet \mathrm{R} \bullet \mathrm{SVNT} \bullet \mathrm{QVAM}$ 


\section{Commentary:}

1. 1: the letters are written between two incised lines;

1. 2: the rising right stroke of a $\mathrm{V}$ is visible at the beginning of the line;

1. 6: before the I at the beginning of the line the upper horizontal stroke of a $\mathrm{T}$ has survived;

1. 8: NT at the beginning;

1. 9: at the beginning the traces of the upper right stroke of an $\mathrm{V}$ - at the end clearly INSTITVEREN;

1. 10: at the beginning clearly TARE;

1. 12, left side: the tablet broken along the upper part of a vertical stroke, therefore ITVVM at the beginning of the line;

1. 13: not absolutely clear if EX• or EX[- 2-3 -]TIRIS;

1. 14: alternatively T QVI on the left side.

\section{The heading}

[- - -]PEIO in the heading must belong to a Roman name like Ampeio, Appeio, Pompeio, or Tarpeio. ${ }^{4}$ Since Ampeius, Appeius, and Tarpeius are quite rare compared to Pompeius, the latter is our first choice. This conclusion is confirmed by the fact that from these names only Pompeius is attested as a nomen of Roman consuls.

During the reign of Emperor Tiberius (AD 14 - 37), who is mentioned in line 4 and again in line 6 , only one consul bearing this nomen gentile is known, Sextus Pompeius. ${ }^{5}$ He was elected together with Sextus Appuleius. ${ }^{6}$ Both held this office for the whole twelve months in AD 14, the year in which Augustus passed away. Tacitus writes that both consuls were the first to swear allegiance to Augustus' heir, Tiberius. ${ }^{7}$ As in the inscriptions CIL III 7301, CIL VI 10286-10287, or in AE 1972, 154, the first line must be restored as follows: Sex(to) Appuleio Sex(to) Pompeio co(n)s(ulibus).

\section{The main text}

At the beginning of line 2 the right stroke of an $\mathrm{V}$ can be seen. [- - - ]VI almost certainly can be restored as [- - q]ui due to the following subordinate sentence. So line 2 refers to people qui sub signis sunt - soldiers (and partially even veterans?) who are serving in the Roman army. QVAM at the end of the line is difficult to determine: was there maybe a construction like tam ... quam? Or does it belong to e.g. quam[diu]?

The still visible $\mathrm{M}$ at the beginning of line 3 is apparently not part of the following imperial name (in the dative case), Aug(usto) patri, followed by the verb praestiterunt. The lost word ending with $\mathrm{M}$ and praestiterunt seem to be connected. For instance, it would be possible to restore terms like fidem, obsequium, or officium. This could give meaning to this line. Further arguments for a more specific restoration can be derived from line 4: there seems to be a parallel in the construction of

\footnotetext{
${ }^{4}$ Mócsy 1983, 355.

${ }^{5} \mathrm{PIR}^{2} \mathrm{P} 584$.

${ }^{6} \mathrm{PIR}^{2}$ A 962. Cf. e.g. Swan 2004, 299.

${ }^{7}$ Tac. ann. 1, 7, 2: Sex Pompeius et Sex. Appuleius consules primi in verba Tiberii Caesaris iuravere ... - "The consuls Sextus Pompeius and Sextus Appuleius were the first to swear (allegiance) to Tiberius Caesar ...”.
} 
the sentence and of the terms used: obsequium followed by a name in the dative case, Ti(berio) Caesari / [Augusto. It would be attractive to connect it with the verb pra]estare in line 5, but since the total length of line 5 is unknown, this ougth to remain a mere hypothesis. With this in mind the following restoration for line 3 is proposed: [- - obsequiu?]m Aug(usto) patri praestiterunt.

Line 6 is important because the full name of the emperor can be read, Tiberius Caesar Augustus (in the genitive case). Unfortunately the term or object, to which the genitive case refers, is unknown. On the other hand, maybe a connection can be drawn between idque eos in line 5 and the verb facere in line 6. Once again, however, we have to consider that the length of line 6 remains as an unknown factor for the reconstruction of the lost text.

commoda in line 7 mean 'privileges and benefits' ${ }^{8}$ Various examples demonstrate that it was commonly used in connection with soldiers and veterans: de commodis militum veteranorum augendis ... (Cic. Phil. 5.53), de militum commodis fuit tibi curae (Cic. Fam. 10.24.2), de commodis eorum (sc. veteranorum) (Cic. Fam. 11.2.3), or stipendia ... militum et commoda veteranorum (Suet. Nero 32). Hence, we are tempted to connect commoda eorum to privileges granted to soldiers and/or veterans. I would hesitate to restore MAGN at the end of this line as magn [a] and to connect it with commoda, as this structure would be too elaborate here. On the other hand, it must be taken into consideration that MAGN could also be the first half of magnitudo or similiar.

At the end of line 8, after AVCTO, there is space for about two letters. Hence, aucto should be understood more likely as an ablative absolute of the verb augere than, for instance, aucto[ritas].

At the beginning of line 9 traces of a rising stroke are visible (but not easily discernible on the photo). I am tempted to restore $d]$ ua or, alternatively, no]ua, followed by the next important keyword, vectigalia. At the end both verb forms institueren[tur] and institueren[t] could continue in the following line.

It is difficult to determine the precise meaning of line 10. At the beginning TARE can be read. It could be the infinitive ending of a verb, or it could be the end of an adjective. ex patrimoniis is clear, and $\mathrm{OM}$ at the end should most likely be om[nium or om[nibus. Was money ex patrimoniis used to finance the privileges of the soldiers and veterans? If we connect ex patrimoniis to the financing of the commoda, TARE could be restored as militare, and more specifically as aerarium militare. If we take this for granted, there would be a direct connection to the system of funding the aerarium militare, which was established by Augustus in the year AD $6^{9}$ and later on modified by Tiberius. Augustus mentiones in his res gestae (17.2): ${ }^{10}$

Et M(arco) Lep[i]do et L(ucio) Arruntio co(n)s(ulibus) i[n] aerarium militare quod ex consilio $m[e o] / c o[n] s t[i t u]$ tum est ex [qu]o praemia darentur militibus qui vicena / [aut plura s]tipe[ndi]a emeruissent HS milliens et septing[e]nti/[ens ex pa]t[ri]monio [m]eo detuli. - »And in the consulship of M. Lepidus and L. Arruntius I contributed 170.000.000 sesterces out of my own patrimonium to the military treasury, which was established on my advice that from it gratuities might be paid to soldiers who had been serving for twenty or more years." ${ }^{11}$

\footnotetext{
${ }^{8}$ Cf. ThLL 3 (1906-1912) Sp. 1928-1929.

${ }^{9}$ Cf. Günther 2008, 34-37 with the remark that a still untitled aerarium was already established in AD 5.

${ }^{10}$ See the reading and transcription in Mitchell - French 2012, 92.

${ }^{11}$ Translation by F.W. Shipley, slightly modified by the author.
} 
Augustus speaks only of his own patrimonium. But here we find the expression ex patrimoniis. If we accept the restoration related to taxes and the military treasury, then the resources of at least two patrimonia were used. On the other hand, we also have to take into consideration the possibility that patrimonia means the patrimonies of soldiers and veterans. Conceivable, for instance, would be that the granted privileges include the exemption of (all?) patrimonies of soldiers and veterans from (special) taxes or munera? ${ }^{12}$ However, the precise meaning of this line remains unclear due to the fragmentary character of the text.

Missio is the keyword of line 11. Together with the aforementioned terms it is a strong hint for a system of regulations regarding the discharge of soldiers.

The surviving part of line 12 mainly consists of the terminus proponere. It can be understood here in the sense of making something known to someone. ${ }^{13}$ ITVVM at the beginning fits to the genitive plural exerc]ituum, so that an appropriate reconstruction could be: [- - - in contionibus exerc]ituum • proponeretur.

A lacuna of two or three letters is found in line 13 after EX. It is difficult to find a convincing solution for filling in the gap ..tiris, which is most likely connected to gentibus.

The reading of the first four letters in the last line is not unambiguous. Both TO VT and T QVI are possible. The following letters P R are clearly divided by a dot. Hence, a reading as pr(aetor) or $\operatorname{pr}$ (ocurator) has to be ruled out. More plausible is $p$ (opulus) $R$ (omanus), in any case.

With all the mentioned restorations the following reading is suggested:

$$
\begin{aligned}
& \text { [Sex(to) Appuleio Sex(to) Pom]peio • co(n)s(ulibus) } \\
& {[- \text { - q] ui } \bullet \text { sub } \bullet \text { signis } \bullet \text { sunt } \bullet \text { quam }} \\
& \text { [- - -obsequiu?]m } \bullet \text { Aug(usto) } \bullet \text { patri } \bullet \text { praestiterunt } \\
& \text { [- - ]E • obsequium Ti(berio) } \bullet \text { Caesari } \\
& \text { [Augusto - - -? pra] estare volverint } \bullet \text { idque } \bullet \text { eos } \\
& \text { [- - ] Ti(berii) • Caesaris • Augusti } \bullet \text { facere } \\
& \text { [- - - }] \text { I c commoda } \bullet \text { eorum } \bullet \text { MAGN- } \\
& \text { [- - ]NT • sed } \bullet \text { etiam } \bullet \text { quia } \bullet \text { aucto } \\
& \text { [ - - no]ua or [- - d]ua } \bullet \text { vectigalia } \bullet \text { institueren- } \\
& \text { [t or -tur - - - ] tare } \bullet \text { ex } \bullet \text { patrimoniis } \bullet \text { om- } \\
& \text { [nibus or -nium - - -s] imul cum missione } \\
& \text { [- - - in contionibus? exerc]ituum } \bullet \text { proponeretur } \\
& \text { [- - - ]SE • ex . . TIRIS • gentibus } \\
& \text { [- - ]TQVI? •p(opul-) } \bullet \text { R(oman-) } \bullet \text { sunt } \bullet \text { quam }
\end{aligned}
$$

\footnotetext{
${ }^{12}$ For the benefits and privileges of veterans in general see Wesch-Klein 2007 with further bibliography.

${ }^{13}$ Cf. ThLL 10,2 $2^{3}$ (1980-2009) 2058-2076, esp. 2060-2061.
} 
Translation: "In the consulship of Sex. Appuleius and Sex. Pompeius ... who were serving in the army ... they showed (obedience?) to (my) father Augustus ... they will have been showed obedience to Ti. Caesar Augustus and this ... they ... to do ... of Ti. Caesar Augustus ... their gratuities ... but even because (after?) the augmentation ... new (or two?) taxes were introduced ... from the patrimonies of ... together with the dismissal ... (the assembly?) of the army was informed ... from the ..TIRIS tribes ... the Roman people ...."

\section{The date of the document}

The first line gives the consular date, AD 14. As already stated, maybe the precise date or issueing authorities were given in the line between the heading and line 1 of the main text. At the moment, however, this remains only an unproven hypothesis.

A further conclusion can be drawn from the name of the emperor. Tiberius Caesar Augustus (1. $4-5,6)$ indicates a date in the second half of that year, after Augustus' death on the $19^{\text {th }}$ of August. Since the imperial cognomen Augustus was inherited from his predecessor, ${ }^{14}$ Tiberius would not have used it before the public opening of the will of Augustus. This took place during the first senate meeting after the death of Augustus, according to Wilhelm Weber on the $3^{\text {rd }}$ or $4^{\text {th }}$ of September. ${ }^{15}$ During these period Tiberius did not assume all of the titles offered to him. Dio reports in summary which parts of the imperial titulature Tiberius rejected: ${ }^{16}$ the praenomen imperatoris, and the honorary title pater patriae. And which parts he »unwillingly" used: »That of Augustus he did not assume, -in fact he never permitted it to be even voted to him,- but he did not object to hearing it spoken or to reading it when written, and whenever he sent messages to kings, he would regularly include this title in his letters." 17 The acceptance of the cognomen Augustus is dated to the $17^{\text {th }}$ of September, the day of the second senate meeting after Augustus' death. ${ }^{18}$ This is the terminus post quem of this document, which dates between the $17^{\text {th }}$ of September and the end of $\mathrm{AD} 14$.

\section{The layout of the document}

The text of the heading, Sex. Appuleio Sex. Pompeio cos., is important for estimating the total width of the whole tablet. The first 17 letters and three triangular dots are missing. The original width can therefore be estimated to measure around $50-60 \mathrm{~cm}$. That means more than two thirds of the original width are lost. In lines 2 to 5 we find 18, 22, 19, and 22 letters respectively. Roughly estimated, each line consisted of ca. 60-70/75 letters. ${ }^{19}$

\footnotetext{
${ }^{14}$ Suet. Aug. 101.2: quos et ferre nomen suum iussit.

${ }^{15}$ Weber 1936, 39-40 with note 197.

${ }^{16}$ Dio 57.8.1-2.

${ }^{17}$ Dio 57.8.1. (translation by E. Cary, Loeb edition). Cf. Weber 1936, 57*-59* n. 231 and 232.

${ }^{18}$ Bleicken 1998, 667; Kienast et al. 2017, 71.

${ }^{19}$ There is a vague hint that the text was perhaps incised in two columns. Line 5 doubtlessly started with Augusto, then presumably followed by pra]estare, altogether ten letters. That would make 32 letters in this line, and it would be enough to fill out one of two columns. At the moment this remains a hypothesis, but it should be kept in mind. Only with new fragments we can gain certainty on this matter.
} 


\section{The recipients of the document}

The recipients of this document are members of the Roman legions, here generally called qui sub signis sunt. Keywords like obsequium, commoda, and missio point to the military sphere as well. Furthermore, if we accept the restoration in line 12, in contionibus exerc]ituum proponeretur, then the document most likely concerns the entire Roman army and not only parts of it like, for instance, the exercitus inferior or superior, which were based at the Rhine frontier. Hence, exempla of it must have existed in many places. It remains unclear if bronze tablets like this one were fixed on public walls also in cities, as was the case with the senatus consultum de Cn. Pisone patre of the year AD 20. It was decreed by the Senate that the latter should not only be published in cities, but also in the winter quarters of each legion: in hibernis cuiusq(ue) legionis ad signa figeretur. This is most likely the place where the bronze copies of this document were also fixed.

\section{The historical background}

The death of the first Roman princeps caused a critical situation. Tiberius, as the designated successor, had to establish his position in Rome. At the same time he faced mutinies of legions in two border regions of the Roman Empire. Tacitus - our main source - reports that disorder developed within three legions in Pannonia and in the army stationed in Germania. ${ }^{20}$ Their demands were, as summarized by Dio, that their term of service should be reduced from 20 to 16 years, that they should be paid a denarius per day, and that they should receive their praemia in the camp. ${ }^{21}$ In order to end the uproar and to restore order, Tiberius sent his son Drusus to Pannonia, ${ }^{22}$ while his adopted son Germanicus successfully negotiated with the soldiers of the army of Lower Germany. However, not only the emperor and the two princes were involved, but also the Senate. Tiberius announced in a letter to the soldiers (carried and read by Drusus) that he would lay their demands before the senators, ${ }^{23}$ and envoys from the Senate were also sent to Germanicus. ${ }^{24}$ Later we hear that the Pannonian legions had sent a petition to Tiberius and waited for a letter from him. $^{25}$

The text of the bronze fragments presented here is apparently influenced by this situation. The mentioning of obsequium to Tiberius Caesar Augustus (1. 4-5) is important in or after a situation of unrest, while commoda and later missio reflect aspects of the soldiers' demands. Moreover, [in contionibus exerci]tuum proponeretur shows that the army was informed about regulations. That not only the emperor and the army were involved may be concluded from the mentioning of the populus Romanus in the last line, though the precise context remains unclear. As already mentioned, it is clear from the literary sources that the Senate also played a role. In this context it should be noted that in his description of the events in Cologne, Tacitus also mentions a senatus

\footnotetext{
${ }^{20}$ Tac. ann. 1.16-30 (Pannonia) and 1.31-46 (Germania). Cf. Vell. 2.125.1-5; Dio 57.4-5.

${ }^{21}$ Dio 57.4.2.

${ }^{22}$ Drusus left Rome after the $17^{\text {th }}$ of September and reached the mutinous troops on the $26^{\text {th }}$ of September, cf. the chronology given by Swan 2004, 299.

${ }^{23}$ Tac. ann. 1.25. According to Tacitus, Tiberius emphasized in this letter his praecipua fortissimarum legionum cura - "his particular care for the very brave legions".

24 Tac. ann. 1.39.

${ }^{25}$ Tac. ann. 1.30 .
} 
consultum. ${ }^{26}$ Unfortunately nothing is known about its detailed arrangements, but, according to Tacitus, it caused apprehenions within the soldiers that the privileges already granted to them could be revoked. ${ }^{27}$ In summary, both Drusus and Germanicus were able to take back control of the armies in the course of autumn AD 14. Which concrete concessions were made to the soldiers by Tiberius or the Senate is not recorded.

According to Tacitus, Tiberius decided in $\mathrm{AD} 15$ to also use the revenues of the centesima rerum venalium, the one per-cent tax on goods sold at auctions, for financing the aerarium militare. ${ }^{28}$ Obviously the revenues gained by the vicesima hereditatium, which was newly established by Augustus in AD 6 to provide money to the military treasury, were not sufficient for financing the retirement benefits (praemia veteranorum) ${ }^{29}$ At the same time the length of service was regulated and fixed at 20 years, with the argument that the state only could bear the financial burden of the cash gratuities nisi vicesimo militiae anno veterani dimitterentur -»if the veterans were dismissed after twenty years of service" ${ }^{30}$ By the way, this is a revealing example of imperial fiscal policy.

On the fragments presented here $d]$ ] ua or no]ua vectigalia are most likely mentioned. Both possible restorations lead to the question of how this tablet should be connected to the aforementioned events in late $\mathrm{AD} 14$ and $\mathrm{AD} 15$. Was it immediately engraved and published after the unrest and its regulations then revised in the following year? Or does the tablet already contain the revised regulations? The restoration d]ua or no] ua vectigalia can be taken as a hint maybe for the latter. In this case, were the arrangements reported by Tacitus for AD 15 already made and published in late $\mathrm{AD} 14$ ? Whatever, only further fragments of this bronze tablet can provide more certainty on this question.

\section{Bibliography}

Bleicken 1998

J. Bleicken, Augustus, Berlin² 1998.

Caballos Rufino et al. 2018 A. Caballos Rufino - O. Rodríguez Gutiérrez - L. Brassous, Aes colletaneus: fragmentos de bronces iuridicos procedentes del foro de Baelo Claudia, AEspA 91, 2018, 39-54.

Eck - Caballos - Fernández W. Eck - A. Caballos Rufino - F. Fernández, Das Senatus Consul1996 tum de Gn. Pisone Patre, München 1996.

\footnotetext{
${ }^{26}$ Tac. ann. 1.39.2: utque mos vulgo quamvis falsis reum subdere, Munatium Plancum consulatu functum, principem legationis, auctorem senatus consulti incusant. - "And as it is the way with a mob to fix any charge, however groundless, on some particular person, they reproached Munatius Plancus, an ex-consul and the chief envoy, with being the author of the Senate's decree."

${ }^{27}$ Tac. ann. 1.39.1: pavidos et conscientia vaecordes intrat metus venisse patrum iussu qui inrita facerent quae per seditionem expresserant. - "Nervous as they were and distraught with the consciousness of guilt, the fear came over them that senators had come with the order to revoke all the concessions they had extorted by mutiny."

${ }^{28}$ Tac. ann. 1.78.2: centesimam rerum venalium post bella civilia institutam deprecante populo edixit Tiberius militare aerarium eo subsidio niti. - "When the people asked for a remission of the one per cent tax which had been established after the civil wars, Tiberius declared by edict that the military treasury depended on that branch of revenue." - Cf. Günther 2008, 127-132. Keppie 1996, 378.

${ }^{29}$ The ordinary praemium was 12.000 HS for a legionary soldier. According to modern estimates, 4.0005.000 legionaries were dismissed each year. Cf. Mann 2000 with further literature.

${ }^{30}$ Tac. ann. 1.78.2.
} 
González 1986

Günther 2008

Keppie 1996

Kienast et al. 2017

Mann 2000

Mitchell - French 2012

Mócsy 1983

Swan 2004

Weber 1936

Wesch-Klein 2007

Wolf 2011
J. González, The lex Irnitana: a new copy of the Flavian municipal law, JRS 76, 1986, 147-243.

S. Günther, „Vectigalia nervos esse rei publicae”. Die indirekten Steuern in der Römischen Kaiserzeit von Augustus bis Diokletian, Wiesbaden 2008.

L. Keppie, The Army and the Navy, CAH X, 1996, 371-396.

D. Kienast et al., Römische Kaisertabelle. Grundzüge einer römischen Kaiserchronologie, Darmstadt ${ }^{6} 2017$.

J. C. Mann, Honesta Missio from the Legions, in: G. Alföldy - B. Dobson - W. Eck (eds.), Kaiser, Heer und Gesellschaft in der römischen Kaiserzeit. Gedenkschrift für Eric Birley, Stuttgart 2000, 153-161.

S. Mitchell - D. French, The Greek and Latin Inscriptions of Ankara (Ancyra), vol. 1, München 2012.

A. Mócsy, Nomenclator provinciarum Europae Latinarum et Galliae Cisalpinae cum indice inverso, Budapest 1983.

M. P. Swan, The Augustan Succession: An Historical Commentary on Cassius Dio's Roman History, Oxford 2004.

W. Weber, Princeps. Studien zur Geschichte des Augustus. Band I, Stuttgart-Berlin 1936.

G. Wesch-Klein, Recruits and Veterans, in: P. Erdkamp (ed.), A Companion to the Roman Army, Oxford 2007, 435-450.

J. G. Wolf, Die Lex Irnitana: ein römisches Stadtrecht aus Spanien, Darmstadt 2011. 


\section{İmparator Tiberius ve İ. S. 14 Tarihli Yeni Bir Bronz Tablette Onun praecipua legionum cura'sı}

Öz

Bu makalede İ. S. 14 yılına tarihlenebilecek büyük bir yazıtlı bronz levha parçası incelenmektedir. Belgenin muvazzaf askerler ile emekli askerlerin (veteran) ayrıcalıklarına ve veteranların finansmanına yönelik düzenlemeler içerdiğini saptamak mümkündür. Bu düzenlemeler Ren ve Tuna sınırlarındaki lejyonların Augustus'un ölümünden sonrasında başlattıkları ayaklanmalardan sonra yapılmıştır. Çoğu yeri kırık olan yazıtın yaklaşık çevirisi:

“Sex. Appuleius ve Sex. Pompeius'un konsüllükleri döneminde ... orduda hizmet eden (filanca/lar) ... babam Augustus'a itaat etmişler .... Ti. Caesar Augustus'a da itaat edeceklerdir ve bu ... onlar ... yapmak için ... Ti. Caesar Augustus'un ... şükranları ... hatta çoğalmasından (sonra?) .... yeni (ya da iki?) vergi yürürlüğe kondu ... ...'nın miraslarından ... azledilmeleriyle birlikte ... ordu (konseyi?) bilgilendirildi .....TIRIS boylarından ... Roma Halkı...”.

Anahtar Sözcükler: Tiberius, bronz tablet, Roma ordusu, resmi belge, aerarium militare, veteranlar, ayricalıklar.

\section{Emperor Tiberius and His praecipua legionum cura in a New Bronze Tablet from AD 14}

\section{Abstract}

Fragments of a huge inscribed bronze tabula are presented here, which can be dated to the end of the year $\mathrm{AD} 14$. The document contained regulations regarding the privileges of soldiers and veterans as well as the financing of the latter. These regulations were made after the mutinies of legions at the Rhine and Danube frontiers, which started after the death of Augustus.

Keywords: Tiberius, bronze tablet, Roman army, state document, aerarium militare, veterans, privileges. 